\title{
KONSEP PEMBELAJARAN DALAM LAKON WAYANG DEWA RUCI
}

\author{
Febranti Putri Navion, Febri Tri Cahyono \\ Universitas Islam Negeri Sayyid Ali Rahmatullah Tulungagung \\ Email: febranti.bki@gmail.com
}

\begin{abstract}
The focus of this research is to take the value of learning concepts that include the learning process, learning through experience (Experiential Learning), motivation and independence, which is taken by Dewa Ruci. This study uses qualitative design with a Hermeneutics approach. Hermeneutic approach that serves as a tool to trace or reveal meaning in text, discourse, and interpret problems such as in the text and Dewa Ruci story. The value of the learning concept includes, 1) the concept of the learning process, the teacher gives assignments in accordance with the abilities of the students. In addition, students are expected to have traits possessed by Bima, namely clever, hard character, soft heart, curiosity, sensitive in utilizing learning media, able to know the purpose of learning, and able to adapt; 2) learning through experience (Experiential Learning); 3) motivation that explains that every individual who wants to successfully achieve his/h learning goals the first requirement that must be met is a strong and great puzzle, willpower, motivation; 4) selfreliance. Self-reliance can be obtained by students through self-reflection.
\end{abstract}

Keywords : Ruci God, Learning

\begin{abstract}
Fokus penelitian ini adalah mengambil nilai konsep pembelajaran yang meliputi proses pembelajaran, pembelajaran melalui pengalaman (Experiential Learning), motivasi dan kemandirian, yang diambil oleh Dewa Ruci. Penelitian ini menggunakan desain kualitatif dengan pendekatan Hermeneutika. Pendekatan hermeneutik yang berfungsi sebagai alat untuk menelusuri atau mengungkap makna dalam teks, wacana, dan menafsirkan masalah seperti dalam teks dan cerita Dewa Ruci. Nilai konsep pembelajaran meliputi, 1) konsep proses pembelajaran, guru memberikan tugas sesuai dengan kemampuan siswa. Selain itu siswa diharapkan memiliki sifat-sifat yang dimiliki Bima yaitu pandai, berwatak keras, lembut hati, rasa ingin tahu, peka dalam memanfaatkan media pembelajaran, mampu mengetahui tujuan pembelajaran, dan mampu beradaptasi; 2) belajar melalui pengalaman (Experiential Learning); 3) motivasi yang menjelaskan bahwa setiap individu yang ingin berhasil mencapai tujuan belajarnya syarat pertama yang harus dipenuhi adalah teka-teki, kemauan, motivasi yang kuat dan hebat; 4) kemandirian. Kemandirian dapat diperoleh siswa melalui refleksi diri.
\end{abstract}

Kata Kunci : Dewa Ruci, Pembelajaran 


\section{PENDAHULUAN}

Indonesia memiliki kekayaan budaya lokal yang tersebar dari ujung barat hingga ujung timur. Setiap daerah memiliki ciri khas tersendiri sesuai dengan daerah masing-masing. Ciri khas budaya mengandung nilai-nilai kehidupan yang beranekaragam membuat bangsa lebih kokoh dan kuat. Budaya yang mewariskan dengan banyak nilai-nilai dan kearifan lokal berperan penting dalam membangun bangsa sebagai manusia indonesia seutuhnya. Nilai-nilai dan kearifan lokal dari budaya-budaya di Indonesia memang banyak mengandung makna-makna filosofis yang bernilai dan bermanfaat untuk diterapkan dalam kehidupan. Nilainilai tersebut dapat berasal dari berbagai sumber seperti seni, bangunan, atau sastra. Salah satu sumber nilai yang cukup terkenal dikalangan bangsa Indonesia adalah kesenian wayang di jawa. Wayang merupakan sebuah pertunjukan panggung tradisional yang biasanya menceritakan kisah yang diadaptasi dari cerita Ramayana dan Mahabharata yang berasal dari India. Selain cerita adaptasi Ramayana dan Mahabharata cerita wayang juga menceritakan berdasarkan cerita lama yang berasal dari Indonesia. Bentuk wayang yang ada di Indonesia terdiri dari berbagai macam bentuk, antara lain pahatan patung, kulit, bahkan rumput.

Wayang kulit merupakan salah satu bentuk wayang yang popular dipertunjukan di masyarakat jawa yang memiliki cerita yang menarik dan memiliki makna-makna dalam setiap lakon pertunjukannnya. Di jawa wayang dianggap sebagai salah satu media menyampaikan pesan dalam bentuk cerita ataupun makna yang terkandung dalam simbol pada suatu benda. Begitu kentalnya budaya pewayangan yang melekat dalam kehidupan masyarakat Indonesia khususnya jawa ditunjukan dengan masih banyaknya keyakinan yang dipengaruhi cerita wayang, misalnya tradisi ruwat, dan kepercayaan tentang asal-usul tempat dan cerita sejarah pulau jawa yang seringkali dikaitkan dengan kisah atau tokoh pewayangan.

Wayang merupakan salah satu kebudayaan yang memiliki nilai yang begitu luar biasa diantara peninggalan budaya yang ada di Indonesia. Budaya pewayangan yang dijadikan media menyampaian informasi yang syarat akan nilai agama moral, sosial, emosional, pendidikan, hiburan, filsafat merupakan bentuk eksistensi nilai budaya yang tinggi dalam setiap cerita, dan karakter dalam pewayangan. Setiap cerita dan tokoh dalam pewayangan merupakan simbol kehidupan yang jika dipahami maknanya akan mengarahkan kita kepada nilai-nilai kehidupan yang dapat dijadikan salah satu referensi untuk dikembangkan menjadi sumber pembelajaran dalam bersikap dan berperilaku di kehidupan sehari-hari. Digunakannya referensi budaya pewayangan tentunya tidak serta merta menelan mentah-mentah perilaku tokoh pewayangan atau cerita dalam pewayangan, sebelum digunakan menjadi salah satu referensi untuk pedoman bersikap dan berperilaku dalam kehidupan cerita dan perilaku tokoh pewayangan harus dimaknai secara mendalam. Menurut Manuaba, (1999) budaya daerah akan memiliki nilai yang bermakan dan juga mendapatkan penghargaan jika sudah dilakukan upaya pemberian makna.

Salah satu tokoh wayang yang menarik dan kaya akan nilai luhur adalah kisah Bima dalam lakon Dewa Ruci. Dalam salah satu pertunjukan wayang lakon Dewa Ruci dalang memulai pagelaran wayang dengan menampilkan dialog dua ekor burung yang membicarakan dan mengamati bagaimana tingkah laku manusia yaitu Bima dalam 
mencari ilmu. Dialog sebelum pagelaran wayang ini mengisyaratkan bahwa cerita Bima dalam lakon Dewa Ruci dalam pewayangan merupakan cerita yang menyampaikan tentang perjalanan seseorang Bima dalam mencari ilmu (belajar). Cerita ini memiliki banyak nilai yang dapat diambil untuk diterapkan dalam berkehidupan salah satu nilai yang dapat diambil adalah nilai konsep pembelajaran dalam lakon Dewa Ruci. Fokus konsep pembelajaran yang diambil maknanya dari lakon Dewa Ruci dalam paparan ini adalah tentang proses pembelajaran, belajar melalui pengalaman (Experiential Learning), motivasi belajar dan kemandirian belajar.

\section{METODE PENELITIAN}

Penelitian ini menggunakan rancangan kualitatif dengan pendekatan Hermeneutika Bersusun. Metode kualitatif memiliki ciri data yang disajikan dalam bentuk deskripsi yang berupa kata-kata, ungkapan, teks naratif, pendapat, serta gagasan yang dikumpulkan oleh peneliti dari berbagai sumber sesuai dengan teknik pengumpulan data yang dilakukan. Selanjutnya, data yang didapat dikelompokkan berdasarkan kebutuhan dengan pendekatan interpretative terhadap subjek selanjutnya dianalisis (Denzin dan Lincoln, 2005).

Hermeneuitika berkaitan erat dengan upaya menjelaskan dan menelusuri pesan dan pengertian dasar dari sebuah ucapan yang menimbulkan kebingungan pendengar atau pembaca. Pendekatan hermeneutika yang berfungsi sebagai alat untuk menelusuri atau mengungkap makna dalam teks, wacana, dan menginterprestasikan permasalahan seperti dalam teks dan lakon wayang Dewa Ruci.

\section{HASIL DAN PEMBAHASAN}

Dalam lakon Dewa Ruci di ceritakan pihak Kurawa (negeri Astina), ingin menjatuhkan Pandawa (negeri Amarta), melalui perantaraan Guru Durna dengan jalan membinasakan dahulu Bima pelindung terkuat Pandawa. Pendita Durna adalah guru para Pandawa sekaligus Kurawa, atas permintaan kurawa kemudian Durna memanggil Bima.

Durna: "Bima kesinilah, kau adalah muridku yang paling pandai, meskipun watakmu keras tapi kau memiliki hati yang lembut kamulah muridku yang mampu menguasai ilmu "kaweruh sangkan paraning dumadi (asal dan tujuan hidup" dengan syarat carilah dulu "kayu gung susuhe angin"

Bima: "dimanakah "kayu gung susuhe angina" itu berada?"

Durna : letaknya ada di Bukit Candra Muka di hutan Tibrasara kamu sendirilah yang dapat menemukannya aku hanya merestuimu.

Penggalan cerita ini mengisyaratkan bahwa Bima adalah murid yang sudah memiliki kemampuan untuk mendapatkan ilmu yang lebih tinggi dalam hal ini Durna bukanlah semata-mata orang jahat yang ingin mencelakakan muridnya atas dasar perintah Kurawa tetapi seorang yang cerdas yang dapat mengambil sebuah solusi yang dapat memecahkan masalahnya dengan kurawa sekaligus mengajarkan ilmu kepada Bima. Durna tidak memberitahukan letak sarang angin bermakna bahwa guru dapat membebaskan siswa untuk belajar mandiri dengan syarat guru mengetahui seberapa kesiapan siswa dalam menyelesaikan tugas yang diberikan untuk muridnya. Sejalan dengan itu Slameto (2010: 113) mengatakan, kondisi kesiapan individu dalam belajar mencakup setidaknya tiga aspek. (a) Kondisi fisik, mental dan emosional; (b) Kebutuhan, motif, dan tujuan (c) keterampilan dan pengetahuan. Dalam konteks ini Durna 
setidaknya sudah mengetahui ke 3 aspek tersebut sudah ada dalam diri Bima. Selain ketiga aspek tersebut ditinjau dari isi percakapan awal tersebut Durna menyebutkan bahwa ada tiga aspek spesifik penting yang sudah terdapat dalam diri Bima yaitu pandai, watak yang keras dan hati yang lembut.

Aspek pertama adalah kepandaian, maksud dari kepandaian bukanlah sematamata seorang yang pandai saja yang pantas mendapat ilmu akan tetapi menerangkan bahwa kemampuan siswa dalam menangkap dan mempelajari suatu ilmu dipengaruhi oleh tingkat intelegensi. Intelegensi menurut Azwar (2004:21) merupakan salah satu faktor internal yang mempengaruhi prestasi akademik seseorang. Dari segi intelegensi seorang guru disarankan untuk dapat mengetahui seberapa tingkat intelegensi anak sehingga guru tahu metode tertentu yang relevan dengan kemampuan anak sehingga anak dapat melaksanakananya.

Aspek kedua adalah motivasi. Watak yang keras bisa dimaknai sebagai seseorang dengan tekat kuat yang merujuk pada motivasi belajar seseorang. Motivasi belajar menurut Wlodkowski dan Jaynes (2004:57) adalah merupakan sebuah nilai dan hasrat untuk belajar. Sedangkan menurut Sardiman (2004:69), motivasi belajar adalah keseluruhan daya penggerak di dalam diri siswa yang menimbulkan, menjamin kelangsungan dan memberikan arah kegiatan belajar sehingga diharapkan tujuan dapat tercapai. Aspek kedua ini mencerminkan kepribadian Bima yang selalu berkemauan keras untuk mencapai tujuannya. Sedangkan aspek ketiga adalah hati yang lembut yang menandakan ketenangan seseorang dalam belajar.

Dari ketiga aspek tersebut aspek kedua dan ketiga juga dapat dijadikan menjadi satu aspek saja yaitu ambisi dan tekat yang terkendali. Hasbullah Thabrany
(1994:35) mengatakan orang yang mempunyai ambisi besar dan tekad yang kuat, tidak bisa dibantah lagi bahwa sebagian sukses di tangan. Disamping itu juga dapat lebih menumbuhkan rasa percaya diri, sebagaimana yang dikemukakan oleh Hasballah Thabrany (1994:36) mengatakan ambisi yang kuat namun tidak berlebihan dapat menumbuhkan keyakinan diri dalam mencapai kesuksesan.

Selain ketiga aspek tersebut ada satu aspek yang secara implisit disampaikan dalam penggalan cerita ini yaitu rasa keingintahuan Bima mengenai ilmu yang diajarkan gurunya hal ini terbukti dari kemauan Bima menjalankan perintah gurunya mekipun hanya sedikit petunjuk. Rasa ingin tahu atau coriusity merupakan keingintahuan untuk mengetahui, melihat, atau mengalami sehingga memotivasi perilaku eksplorasi yang diarahkan kepada pemerolehan informasi baru (Litman, 2005: 3). Rasa ingin tahu yang sering digambarkan dalam segi efektifitas positif, dan memperoleh pengetahuan ketika seseorang sudah memiliki rasa ingin tahu maka akan dingaga sebagai ganjaran yang bermanfaat dan sangat menyenangkan (Day dalam Litman, 2005:4)

Selain mengajarkan kemandirian Durna juga menerapkan bahwa pembelajaran yang memandirikan itu dapat dilakukan dengan pengalaman nyata bukan hanya teoritis saja. Mendukung temuan dari tersebut ini pada salah satu pertunjukan wayang dalam lakon Dewa Ruci di awal cerita ketika Durna akan memberikan petunjuk bagaimana Bima dapat memperoleh sarang angin itu Bima mengatakan bahawa "ilmu iku kelakone kanthi laku" yang artinya ilmu itu dapat diperoleh dengan bertindak. Kolb (1984: 21) mengemukakan belajar melalui pengalaman menekankan pada hubungan yang harmonis antara belajar, bekerja serta 
aktifitas kehidupan dengan penciptaan pengetahuan itu sendiri. Durna menyatakan ada dua kemungkinan Bima ketika mencari ilmu yaitu mati atau hidup. Hal tersebut berarti Durna sudah memperhitungkan kegagalan dan keberhasilan dari metode belajar yang dia terapkan kepada muridnya.

Keterangan ini didukung saat Durna berkomunikasi dengan Sangkuni dan bertanya mengapa Pandawa bisa lebih baik daripada Kurawa. Durna menyatakan bahwa cara belajar sekarang itu bukan lagi guru memberikan ilmu kemudian siswa menghafalnya tetapi seorang individu yang belajar itu dapat mengembangkan ilmunya sendiri dengan bimbingan dari guru tidak ada pembedaan ajaran yang di berikan tetapi bagaimana seseorang dapat mengembangkan ilmunya. Menurut Kolb (1984:41) belajar melalui pengalaman merupakan proses dimana pengetahuan diciptakan melalui transformasi hasil pengalaman. Pengetahuan dari kombinasi menangkap dan mentransformasikan pengalaman.

Sepanjang cerita pada awal Bima mendapatkan perintah belajar dari guru Durna, dapat disimpulkan bahwa proses belajar dalam cerita Dewa Ruci mengarah pada metode pembelajaran concrete experience. Kolb (1999:33) mengatakan bahwa dalam menangkap pengalaman sebagian dari individu melihat informasi baru melalui mengalami kongkrit, nyata, merasakan kualitas dunia, mengandalkan indera dan membenamkan diri dalam realitas konkret. Pengalaman konkrit memberikan kesempatan pada individu untuk menghubungkan informasi baru dan informasi lama yang sudah dimiliki sebelumnya dengan cara yang bermakna, yang bisa mengarahkan individu untuk mencapai level kognitif tertinggi dalam proses belajar (Bogdan \& Persyn, 2010:21).
Selanjutnya setelah mendapat perintah dari guru Durna, Bima berjalan lurus hingga dia sampai di Hutan Tibrasara, di lereng Gunung Candramuka. Sesampainya di hutan Bima bertemu dengan dua raksasa yang menghalanginya yang pada akirnya mereka kalah ditangan Bima. Kedua raksasa yang telah dikalahkan bima, ternyata lenyap tidak berbekas, sebab Rukmuka dan Rukmakala adalah penjelmaan betara Indera Bayu, yang dihukum Betara Guru karena melakukan kesalahan. Waktu Bima merasa lelah dan beristirahat di sebuah pohon, Bima mendengar suara dari Batara Indra dan Bayu, yang menyampaikan rasa terimakasih kepada Bima, karena berkat jasanya kutukan yang diberikan padanya telah sirna. Selanjutnya ia mengatakan bahwa air suci memang ada, tetapi tempatnya tidak berada dalam Hutan Tibrasarana. Kemudian Betara Indra dan Bayu menyarankan agar Bima kembali saja dan menanyakan dimana Bima dapat tersebut selanjutnya mereka memberikan mustika air samudera yang pada suatu saat ini akan berguna.

Dari penggalan cerita tersebut dapat diintepretasikan bahwa seseorang dalam mencari sebuah ilmu ada syaratnya yaitu memperoleh "kayu gung susuhe angin" Kayu dalam bahasa jawa juga disebut kajeng. Kajeng sinonim dengan karep, karsa, kemauan, cita cita. Gung, adalah tembung wod yang menghasilkan kata Agung yang artinya besar. Susuhing Angin bila diartikan dalam Bahasa Indonesia menjadi; sarang angin (tempat keluar masuknya nafas) jika disimpulkan maknanya adalah syarat sebelum Bima mendapatkan ilmu "kaweruh sangkan paraning dumadi" yang dimaknai harus memiliki tekad yang besar yang diyakini dalam hati. Jadi setiap individu yang ingin berhasil mencapai tujuan belajarnya syarat pertama yang harus dipenuhi adalah tekat, 
kemauan, motivasi yang kuat dan besar. Selain itu adegan ini juga dapat diartikan sebagai hasil dari kegiatan belajar yang konkret akan membuat seseorang menjadi lebih termotivasi.

Menurut Bogdan \& Persyn (2010:19) aktivitas belajar bisa disebut dengan pengalamam konkrit apabila belajar dapat membangkitkan motivasi individu untuk belajar. Penelitian Darmiany (2004:13) menyatakan bahwa dengan menggunakan metode pembelajaran konkrit dapat meningkatkan regulasi siswa dalam belajar. Jadi kegiatan belajar pengalaman konkrit dalam cerita ini meggambarkan bahwa munculnya situasi tertentu menimbulkan proses belajar yang bersifat spesifik, yang pada akhirnya menimbulkan kepekaan dan pengalaman baru yang nantinya dapat dimanfaatkan untuk menghadapi situasi baru.

Dikatakan "kayuh gung susuhe angin" berada di Hutan Tibrasara, dilereng Gunung Candramuka di hutan tibrasara. Tibra artinya rasa prihatin; sara artinya panah, ini melambangkan pelajaran untuk mencapai lendeping cipta (tajamnya cipta). Tikbrasara artinya sebelum memperoleh ilmu seseorang diharapkan memiliki ketajaman rasa (peka), dan memiliki pemikiran kreatif untuk menciptakan sesuatu yang baru. Candra berarti bulan; muka adalah wajah, jadi yang dimaksud dengan Candramuka dapat diartikan seseorang individu yang ingin belajar dapat memanfaatkan panca indranya sebagai penerang dan petunjuk berbagai pelajaran yang di dapatkannya. Hal ini mendukung pengalaman nyata dalam pembelajaran yang menutut penggunaan indera dalam pembelajaran.

Sebuah pembelajaran akan lebih efektif jika menggunakan media belajar yang dapat mendukung terlibatnya indra dalam proses pembelajaran. Indera yang digunakan dalam proses pembelajaran dapat berupa indera penglihatan, pembau, pengecap dan perasa. Menurut Levie \& Levie (1975:37) penggunaan indera yang paling berpengaruh adalah stimulus visual. Stimulus visual membuahkan hasil belajar yang lebih baik untuk tugas-tugas seperti mengingat, mengenali, mengingat kembali, dan menghubungkan fakta dan konsep. Belajar dengan menggunakan indera pandang dan dengar sekaligus akan memberikan keuntungan bagi siswa. Dari kesimpulan ini, dapat dilihat bahwa model pembelajaran dengan menggunakan media dapat menambah keefektifan penbelajaran yang disampaiakan terutama stimulus visual seperti pada cara belajar Bima pada tahap pertama ini.

Di hutan, Bima diserang oleh dua raksasa yaitu Rukmuka dan Rukmala. Dalam pertempuran yang hebat Bima berhasil membunuh keduanya, ini berarti Bima berhasil menyingkirkan halangan untuk mencapai tujuan. Rukmuka: Ruk berarti rusak, muka artinya wajah ini melambangkan hambatan tidak digunakannya indera atau indera yang dimanfaatkan untuk kegiatan lain diluar proses pembelajaran akan berdampak pada terhambatnya proses belajar seseorang. Rukmakala: Rukma berarti emas, kala adalah bahaya, menggambarkan halangan yang datang dari kemewahan kekayaan material. Makna dari material di sini dapat diartinkan bahwa media yang digunakan oleh seseorang dapat membantu seseorang untuk mendapatkan kemudahan dalam belajar tetapi juga menjadi penghambat, sehingga seorang harus mampu menggunakan media dengan bijak ketika dia menggunakannnya.

Setibanya di Astina, Sang Durna memberitahukan kepada Bima bahwa ia sebenarnya sudah menemukan "kayu gung susuhe angin" itu yaitu berupa dua dewa yang ditemui oleh Bima, tetapi selain itu untuk mendapatkan ilmu "kaweruh 
sangkan paraning dumadi" Bima harus mensucikan diri dengan air suci Perwitasari yang letaknya dilaut. Saat Bima bertanya tentang keberadaan di samudera sebelah mana, lalu Durna menjawab, "kamu nanti akan menemukannya dengan keyakinan pada dirimu, Bima”. Dengan ilmu Jalasengara yang diperoleh dari mustika yang diberikan Dewa Bayu dan Dewa Indra, Bima dapat berjalan menuju pusat samudera seperti berjalan di daratan. Saat berada di dalam samudera Bima diserang oleh seekor naga. Bima dililit oleh naga tersebut sampai sekarat, namun Bima pada saat itu bisa menikam naga dengan kukunya (kuku Pancanaka). Akhirnya Bima pun menang.

Bima masuk ke dalam laut dengan ilmu Jalan Segara yang diberikan oleh Dewa Bayu dan Indra, berarti dalam pembelajaran pada tahap pertama Bima memperoleh cara baru untuk beradaptasi dengan lingkungan yang berbeda. Karena pada lingkungan tertentu seseorang juga harus menyesuaikan caranya agar mereka dapat bertahan. Kolb (1984:31) mengatakan bahwa belajar melalui pengalaman merupakan konsep yang mendeskripsikan proses utama seseorang dalam beradaptasi dari lingkunan sosial dan fisik. Melanjutkan keterangan tersebut Bima sebagai seseorang yang sudah mendapatkan pengalaman nyata berarti sudah memperoleh cara baru dari pengalamannya untuk dapat beradaptasi.

Bima akhirnya tahu bahwa air suci itu tidak ada di hutan, tetapi sebenarnya berada di dasar samudera. Samudera berarti laut yang sangat luas. Laut diibaratkan sebagai sumber ilmu yang sangat luas. Sumber ilmu yang sangat luas tersebut tentu terdapat sumber yang dapat menuntun dan memberikan jalan akan tetapi bisa juga menjadi sumber yang malah menyesatkan atau mencelakaan yang digambarkan dalam cerita sebagai sosok naga.

Bima di samudera bertemu dengan dewa berambut panjang, seperti anak kecil bermain-main di atas laut, bernama Dewa Ruci. Rupa Dewa Ruci ini sama persis dengan Bima tapi dalam wujud kecil. Dewa Ruci mengatakan bahwa di sinilah tempat Air Suci itu. Lalu ia berbicara mengenai silsilah Bima dan menguraikan bahwa seharusnya Bima banyak belajar lagi salah satunya yaitu agar belajar agar sebelum bertindak Bima maka seorang harus mengerti tujuannya terlebih dahulu.

Setelah itu Bima diperintahkan untuk masuk tubuh Dewa Ruci lewat lubang telinga kirinya. Awalnya Bima mentertawakannya, sebab Bima berperawakan besar dan Bima bertubuh kecil. Setelah itu Dewaruci menjelaskan bahwa, semua isi dunia, hutan dengan gunung, samudera dengan semua isinya, tak sesak masuk ke dalam tubuhnya. Atas petunjuk Dewa Ruci, Bima masuk ke dalam tubuh Dewa Ruci melalui telinga kiri maka tampaklah laut luas tanpa tepi, langit luas, tak tahu mana utara dan selatan, tidak tahu timur dan barat, bawah dan atas, depan dan belakang.

Kemudian, Dewa Ruci masuk kedalam tubuhnya sendiri di saat inilah Dewaruci memberikan wejangan kepada Bima. Isi wejangan tersebut adalah,

1) Pancamaya (lima bayangan), ialah gambaran alam semesta yang ditanggapi panca indera manusia dan direkam atau disimpan dalam ketidaksadaran (hatu sanubari) manusia, sebagai pengalaman hidupnya.

2) Catur warna yaitu hitam, merah kuning dan putih.

3) Pramana, yang menyatu dengan diri tetapi tidak ikut merasakan gembira dan prihatin, bertempat tinggal di tubuh, tidak ikut makan dan minum, 
tidak ikut merasakan sakit dan menderita, jika berpisah dari tempatnya, raga yang tinggal, badan tanpa daya. Itulah yang mampu merasakan penderitaannya, dihidupi oleh suksma, ialah yang berhak menikmati hidup, mengakui rahasia zat. Kehidupan Pramana dihidupi oleh sukma yang menguasai segalanya, Pramana bila mati ikut lesu, namun bila hilang, kehidupan sukma ada.

4) Persatuan dan kesatuan manusia dengan Khaliknya

5) Pedoman hidup untuk orang yang memiliki perilaku yang baik adalah hidup dalam mati dan mati dalam hidup. Hidup dalam mati artinya, selagi orang hidup di dunia, orang harus dapat mematikan hawa nafsunya, orang harus tetap hidup di dunia.

Adegan Bima betemu Dewa Ruci merupakan adegan yang dapat dimaknai sebagai refleksi diri bima terhadap pengalamannnya yang digambarkan Dewa Ruci yang merupakan sosok Dewa yang rupanya sama persis dengan Bima. Dikatakan seluruh alam semesta dapat masuk ke dalam tubuh Dewa Ruci, berarti segala sesuatu yang dalam dunia ini merupakan suatu hal yang keseluruhannya dapat dipelajari. Selanjutnya Bima masuk melalui telinga kiri Dewa Ruci di dalam Bima melihat banyak kejadian di situlah Dewa Ruci mengartikan semua yang dilihat oleh Bima. Hal ini berarti dengan merefleksi diri seseorang mampu menangkap makna dari semua kejadian yang mereka alami. Refleksi berarti mengamati lingkungan dari perspektifperspektif yang berbeda, mengamati proses belajar dan membantuk maknamakna tertentu yang dipresepsikan.

Bima bertemu Dewa Ruci setelah dia melalui berbagai pengalaman dan cobaan yang sulit yang pada akhirnya dapat dilaluinya. Cara belajar Bima yang demikian ini menggambarkan modal utama yang digunakan seseorang adalah dengan tindakan dan dari tindakan itu diperolehlah pengalaman-pengalaman yang dapat menjadi bekal untuk pembelajaran berikutnya. Menurut siklus belajar experiential learning Kolb, pengalaman langsung atau konkrit merupakan dasar untuk pengamatan dan refleksi. Refleksi ini berasimilasi dan dipilah menjadi konsep-konsep abstrak dari mana implikasi baru untuk tindakan dapat diambil. Implikasi ini dapat aktif diuji dan berfungsi sebagai panduan dalam menciptakan pengalaman baru (Kolb, 1999:2).

Bima setelah mendengar perkataan Dewa Ruci, hatinya terang benderang, menerima dengan suka hati, dalam hati mengharap mendapatkan anugerah wahyu sesungguhnya. Kemudian Dewa Ruci berkata bahwa "Bima, ketahuilah olehmu, yang kau kerjakan, tidak ada ilmu yang didatangkan, semua sudah kau kuasai, tak ada lagi yang dicari, kesaktian, kepandaian dan keperkasaan, karena kesungguhan hati ialah dalam cara melaksanakan”.

Dalam wejangan ini Dewa Ruci memberikan gambaran bahwa seseorang dalam mencari ilmu tidak boleh asal, mereka harus mengetahui hakikat tujuan dia mencari ilmu karena tidak jarang orang salah paham dalam belajar mereka mengira ilmu yang dicarinya sudah benar tapi ternyata salah dan alhasil sia-sia usaha yang dilakukannya.

Dewa Ruci selesai menyampaikan ajarannya, ketika itu Bima mengatakan kepada Dewa Ruci bahwa dia tidak mau pergi dari situ karena ditempat tersebut Bima sudah merasa cukup dan tidak perlu lagi mencari tidak bingung dan semua sudah dipahami, lalu kembali ke alam kemanusiaan, gembira hatinya, hilanglah kekalutan hatinya dan Dewa Ruci telah 
sirna dari mata, setelah itu bima ceritakan perjalanan dilanjutkan Bima untuk menyampaikan apa yang sudah ditemuinya selama perjalanan. Penutup cerita ini dapat diartikan bahwa setelah mendapatkan ilmu yang cukup dalam sebuah pembelajaran seseorang akan terbuka pengetahuannya, memiliki keyakinan dalam menentukan langkah yang diambil dan mampu menyampaikan ilmu kepada orang lain

\section{KESIMPULAN}

Cerita Dewa Ruci termuat dengan konsep proses pembelajran, belajar melalui pengalaman (Experiential Learning), motivasi, dan kemandirian belajar. Satu, dalam konsep proses pembelajaran guru dapat membebaskan siswa untuk belajar mandiri dengan syarat guru mengetahui seberapa kesiapan siswa dalam menyelesaikan tugas yang diberikan untuk muridnya. Dalam hal ini, siswa diharapkan mampu memiliki empat aspek penting yang dapat dijadikan bekal dalam proses pembelajaran yang sudah terdapat dalam diri Bima yaitu pandai, watak yang keras dan hati yang lembut, serta rasa ingin tahu. Selain itu, siswa yang peka dalam memanfaatkan media pembelajaran, mampu mengetahui tujuan belajar, dan mampu beradaptasi dengan lingkungan dan tuntutan pembelajaran, akan lebih mampu dalam menjalankan proses pembelajaran yang bermakna.

Dua, nilai yang diperoleh dari cerita Dewa Ruci selanjutnya adalah belajar melalui pengalaman (Experiential Learning). Diceritakan bahwa Bima bertemu Dewa Ruci setelah dia melalui berbagai pengalaman dan cobaan yang sulit yang pada akhirnya dapat dilaluinya. Cara belajar Bima yang demikian ini menggambarkan modal utama yang digunakan seseorang adalah dengan tindakan dan dari tindakan itu diperolehlah pengalaman-pengalaman yang dapat menjadi bekal untuk pembelajaran berikutnya.

Tiga, nilai selanjutnya adalah motivasi belajar yang menjelaskan bahwa setiap individu yang ingin berhasil mencapai tujuan belajarnya syarat pertama yang harus dipenuhi adalah tekat, kemauan, motivasi yang kuat dan besar.

Empat, nilai terakhir adalah kemandirian dalam belajar. Kegiatan pembelajaran bertujuan untuk memandirikan siswa, hal tersebut dapat diperoleh dengan pengalaman nyata bukan hanya pengajaran konseptual saja. Kemandirian dalam belajar dapat diperoleh siswa melalui cara refleksi diri. Refleksi diri dapat menjadikan siswa mampu menangkap makna dari semua kejadian yang mereka alami. Refleksi berarti mengamati lingkungan dari perspektif-perspektif yang berbeda, mengamati proses belajar dan membantuk makna-makna tertentu yang dipresepsikan.

\section{REFERENSI}

Andikara S.P. 1984. Unio Mystica Bima. Bandung: ITB

Andikara S.P. 1984. Dewa ruci. Bandung: ITB

Andikara S.P. 1984. Serat Bima Suci. Bandung: ITB

Azwar, S. (2004). Pengantar Psikologi Intelegensi. Yogyakarta: Pustaka Pelajar.

Baumgartner, T.A., \& Jackson, S. 1995. Measurement for evaluation. NewYork: Wm C. Brown Comunications. Inc.

Beaudin, Bard.P dkk.1995. Exsperentian learning: Theoritical Underpinning. Colorado: High Plains Intermountain.

Bogdan, E. \& Persyn, J.2010. Concrete Exsperience: the foundation for students' Value for learning. The teaching professor conference.

Brophy, Jere (2004). Motivating Students to Learning. New Jersey: Lawrence Erlbaum Associates. 
Darmiany. 2004. Penerapan Belajar Eksperiensial Efektif Mengembangkan Self-Regulated Learning Mahasis. (Artikel, Tidak diterbitkan)

Denzin, \& Lincoln. (2005). The SAGE Handbook of Qualitative Research.California: Sage Publisher.

Dimiyati dan Mujiono. 1999. Belajar dan Pembelajaran. Jakarta: Rineka Cipta.

Endraswara, Suwardi. 2003. Metodologi Penelitian Kebudayaan. Gadjah Mada University Press. Yogyakarta.

Fashri, Fauzi. 2007. "Penyingkapan Kuasa Simbol". Yogyakarta: Juxtapose.

Gibbons, Maurice. 2002. The Self Directed Learning Handbook Challenging Adolescent Student to Exel. San Fransisco: Jhon Wiley \& Sons, Inc.

Hamalik, Oemar.2005. Proses Belajar Mengajar. Bumi Aksara: Jakarta.

Hasbullah Thabrany.1994. Rahasia Sukses Belajar. Jakarta: PT. Raja Grafindo.

Jhonson, E.B. 2011. Contetual Theaching And Learning: Menjadikan Kegiatan Belajar Menajar Menjadi Bermakna. Bandung: Mizan Media Utama

Kolb, D.A. 1984. Experiential learning: experience as the source of learning and development. Englewood Cliffs, New Jersey: Prentice-Hall.

Levie, W. Howard dan Levie, Diane. 1975. Pictorial Memory Process. Avcr Vol. 23 No. 1 Spring.

Litman, Jordan. A. 2005. Coriousity and The Pleasure of Learning: Wanting and Liking new Information. Pshycologi Press: USA

Manuaba, Putera. "Budaya Daerah dan Jati Diri Bangsa: Pemberdayaan Cerita Rakyat dalam Memasuki Otonomi Daerah dan Globalisasi". Masyarakat, Kebudayaan dan Politik. Th XII, No 4, Oktober 1999, 57-66.

Paulina, Pannen dkk. 2001. Konstruktivisme dalam Pembelajaran. Jakarta: Ditjendikti, Depdiknas.

Pintrich, Paul R. 2003. Motivation and Classroom Learning. New Jersey:
John Wiley \& Sons, Inc.

Ricoeur, Paul. 2002. The Interpretation Theory, Filsafat Wacana Membedah Makna dalam Anatomi Bahasa, IRCiSoD. Yogyakarta

Sardiman, A.M. 2004. Interaksi dan Motivasi Belajar Mengajar. Jakarta: PT RajaGrafindo Persada

Santrock, John W .2007. Psikologi Pendidikan. Edisi Kedua. Jakarta: Prenada Media Group.

Sardiman, A.M. 2004. Interaksi dan Motivasi Belajar Mengajar. Jakarta: PT Raja Grafindo Persada

Slameto. 2010. Belajar dan Faktor-Faktor yang Memengaruhinya. Bandung: Rineka Cipta

Sugiyono. 2007. Metode Penelitian Kuantitatif, Kualitatif dan R\&D. Bandung: Alfabeta

Wlodkowski, R.J., \& Jaynes, J.H. 2004. Motivasi Belajar. Jakarta: Cerdas Pustaka 